\title{
KREATÍVNE KLASTRE VO VIDIECKYCH OBLASTIACH İ PRÍPADOVÁ ǴÚdIA ZO SLOVENSKEJ REPUBLIKY
}

\section{CREATIVE CLUSTERS IN RURAL AREAS İ A CASE STUDY FROM} SLOVAKIA

\section{ING. KATARÍNA MELICHOVÁ \\ DOC. ING. MÁRIA FÁZIKOVÁ, CSc.}

\author{
Katedra regionalistiky a rozvoja vidieka $\mid$ Department of Regional and Rural Development \\ Fakulta európskych g̛údii a regionálního rozvoja Fac. of European Studies and Regional Development \\ Slovenská poÖohospodárska univerzita v Nitre Slovak University of Agriculture in Nitra \\ $\bowtie$ Trieda Andreja Hlinku 2, 94976 Nitra, Slovak Republic \\ E-mail:xmelichova@is.uniag.sk,maria.fazikova@uniag.sk
}

\begin{abstract}
Anotácia
Teoretický koncept kreatívnych odvetví ako aj výskum v oblasti tejto problematiky bol od zal iatku zameraný primárne na urbanizované prostredie. Tendencia kreatívnych firiem koncentrovaš sa $v$ mestách bola podloğená aj dlhým radom výskumných prác. Avg்ak v posledných rokoch sa objavujú kontroverzné myğienky, ǵe aj vidiecke oblasti disponujú ọpecifickými lokalizal nými faktormi, ktoré vytvárajú podmienky pre rozvoj kreatívnych klastrov. Llánok skúma, ! i takéto kreatívne klastre existujú aj na Slovensku a analyzuje ich dynamiku. Pri identifikácii potenciálnych kreatívnych klastrov vo vidieckych oblastiach bola pouğitá ġandardná metóda analýzy priestorovej koncentrácie ekonomických !̣inností (lokaliza! ný kvocient). Na príklade takto identifikovaného kreatívneho klastra, $v$ rámci prípadovej ğúdie zameranej na hढ̄kovú analýzu jeho vnútornej dynamiky, boli pouǵté metódy sieŠsvej analýzy. Výsledky výskumu preukázali, ǵ́ existujú vidiecke oblasti, v ktorých sa koncentrujú g̣pecifické kreativne odvetvia. Ekonomickú základŔu kreatívneho klastra analyzovaného y prípadovej ğúdii tvoria odvetvie hudby, vizuálneho a scénického umenia a odvetvie remesiel, zatiaŎl o odvetvia vydavate@̆tva, videa, filmu a fotografie a marketingovej komunikácie predstavujú podporné odvetvia vo vzŠ̆hu k jadrovým kreatívnym odvetviam v kreatívnom klastri. Spolol ne s N̦alǵmi relevantnými inğitúciami, ktorými sa ukázali byš predovg்etkým miestne samosprávy, neziskové organizácie a zdruğ́nia a vzdelávacie inġitúcie, tvoria tesne prepojenú sieŠ Väzby medzi nimi, ako nosil e intra a inter-sektorových Ăspill-overñ procesov facilitujú budovanie sociálneho kapitálu a spoloḷ enského konsenzu relevantných rozvojových aktérov $v$ regióne.
\end{abstract}

KŎị ové slová

kreatívne odvetvia, klastre, lokaliza! ná analýza, sieŠvvá analýza

\section{Annotation}

Theoretical concept of creative industries as well as research in this field has been focused primarily on the urban environment. The tendency of creative firms to concentrate in cities has been verified in numerous studies. However in recent years, controversial ideas have been emerging that rural areas also possess specific localisation factors, which create conditions for the development of creative clusters. Article examines whether there are such creative clusters in Slovakia and analyses their dynamic. A standard method of identifying spatial clusters of economic activities (location quotient) was used to identify potential creative clusters in rural areas, where methods of social network analysis were applied in a case study to analyse inner dynamic of the identified cluster. As we found, there are rural areas in which specific creative industries concentrate. The economic base of creative cluster being analysed in the aforementioned case study is comprised of music, visual and performing art industry and crafts industry, while publishing, video, film and photography and advertising 
constitute supporting industries in relation to the core creative industries in the creative cluster. Together they form a highly cohesive cluster along with other relevant institutions, which proved to be mainly local governments, non-profit organizations and associations and institutions of education. These ties, as the conduit of intra and inter-sector spill-over processes facilitate building of social capital and public consensus of relevant development actors in the region.

\section{Key words}

creative industries, clusters, localisation analysis, network analysis

JEL classification: $L 82, D 85, R 12$

\section{Úvod}

Teoretický koncept kreatívnych odvetví ako aj výskum v oblasti tejto problematiky bol od zal iatku zameraný primárne na urbanizované prostredie. Väl g̉na autorov (Florida, 2003; Andersson,1985; Scott, 1997) sa zhodla na tom, ǵe rovnako kreatívne odvetvia a jednotlivci patriaci do kreatívnej triedy majú tendenciu koncentrovaŠ sa v mestách v kontraste s vidieckym prostredím, ! o bolo potvrdené aj kvantitatívnym výskumom (Lorenzen, V. Andersen, 2007), tvrdiac ǵe práve mestské prostredie disponuje jedinel ným súborom lokalizal ných faktorov, ktoré priŠahujú kreatívnych jednotlivcov a kreatívne odvetvia. Týmito lokalizal nými faktormi sú aglomeral né efekty, prítomnosŠ kultúrneho a historického dedil stva a g̣pecializovaná pracovná sila (Lazzarettová, 2009).V uvedených teoretických a výskumných prácach zdôrazŔujeme diskriminal ný postoj ku vidieckym regiónom, v poslednom období sa vğak objavujú aj guúdie tvrdiace, ǵe aj v oblastiach vidieckeho charakteru g̣pecifické lokalizal né faktory vytvárajú podmienky pre vývoj kreatívnych klastrov. Munoz (2010) za najdôleǵitejğe oznaḷje systém vzdelávania, sociálne siete a hustotu interakcií, komunitnú angaǵovanos ̌̌ a prepojenosక́ ! o rozoznávame ako sociálny kapitál, ktorý Florida (2007) nielen, ǵe nepovaǵuje za faktor, ktorý podmieŔuje koncentráciu kreatívnej triedy v priestore, ale dokonca túto koncentráciu brzdí. Markussenová (2006) tvrdí, ǵe pre umelecky zameraných !̣ lenov kreatívnej triedy je práve konektivita $\mathrm{v}$ zmysle sietí !l lenov pôsobiacich a tvoriacich $\mathrm{v}$ rovnakých alebo príbuzných oblastiach a dostupnosŠ priestorov pre stretávanie prioritnejğa v porovnaní s veQ̆xoš̌ou odbytového trhu pre ich výrobky (spätná väzba od kolegov a transfer ideí a poznatkov, ktoré frekventované interakcie a tesnejg̈e sociálne väzby v menğch mestách a vidieckych oblastiach umoǵRujú).

Klasickú Porterovu (2000) definíciu klastra Evans (in Chovanec, Rehák, 2012), z pohădu kreatívnych odvetví povaǵuje za veŎni úzku a tvrdí, ğe kreatívny klaster zahß̌Ra aj Ăneziskové organizácie, kultúrne inğitúcie, dejiská umeleckých podujatí a individuálnych umelcov...ñ a ǵe sú kreatívne klastre Ă..miestami pre ğ́vot, rovnako ako prácu a miestami kde sú kultúrne produkty spotrebovávané a produkovanéñ V súlade s postojom Simona Evansa, Klamer (2011) rozǵril chápanie priestoru, v ktorom pôsobia kreatívne subjekty pri vytváraní kreatívneho obsahu, z pohădu subjektov súkromného sektora ï podniky a podporných (verejných) inġitúcií, o sociálny priestor, ktorý vyjadruje kultúrne hodnoty, kultúrne dedil stvo, identitu a N̦alg̉e. Uvedené definície kreatívnych klastrov ovplyvnili aj konceptualizáciu metodiky príspevku predovğetkým v zmysle definovania jednotlivých typov vzŠahov ako aj subjektov, ktoré boli zahrnuté do výskumu.

\section{CieOa metódy}

CieØ̆m príspevku je identifikovaŠ potenciálne kreatívne klastre vo vidieckych regiónoch a opísaŠich vnútornú dynamiku a väzby na vonkajg̉e prostredie. V príspevku pouǵivame klasifikáciu navrhnutú v rámci výskumného projektu APVV 0101-10 Kreatívna ekonomika ï národohospodárske a regionálne podmienky a stimuly, ktorú sme rozğrili o odvetvie remesiel a umeleckého vzdelávania. Pri identifikácii potenciálnych kreatívnych klastrov sme vychádzali z hodnôt lokalizal ného kvocientu kreatívnych odvetví, pri výpoḷte ktorého sme pouǵli proxy premennú ï poḷ etnosŠ subjektov patriacich do relevantných odvetví. Vzhădom na pouǵitý indikátor koncentrácie a skutol nosti, ǵe priestor chápeme ako diskrétnu velị inu v záujme vyrieǵenia problému MAUP (Modifiable area unit 
problem - Arlinghause et al. (1996)), ktorý vyplýva z agregovania ġatistických dát na jednotlivých úrovniach sídelných jednotiek, pri regionalizácii územia vychádzame z metodiky podă Slavíka (2005), ktorá územie SR rozdeQ̆je do 160 mikroregiónov (nodálne regióny sa vyznaḷjú koherentnejğbu ğruktúrou, keṆǵe boli zostavené na základe vzájomných prepojení a vzŠahov medzi sídelnými jednotkami). Mikroregióny sme následne klasifikovali do ġyroch skupín podă stupŔa urbanizácie (Obr. 1), na základe troch parametrov: hustoty osídlenia, percenta mestského obyvateQ̆tva a veŎosti centrálneho sídla (Fáziková, Stehlíková, 2006) aplikáciou nehierarchickej metódy zhlukovej analýzy (k-means algoritmu).

\section{Obr. 1: Klasifikácia mikroregiónov SR podă stupŔa vidieckosti (2012)}

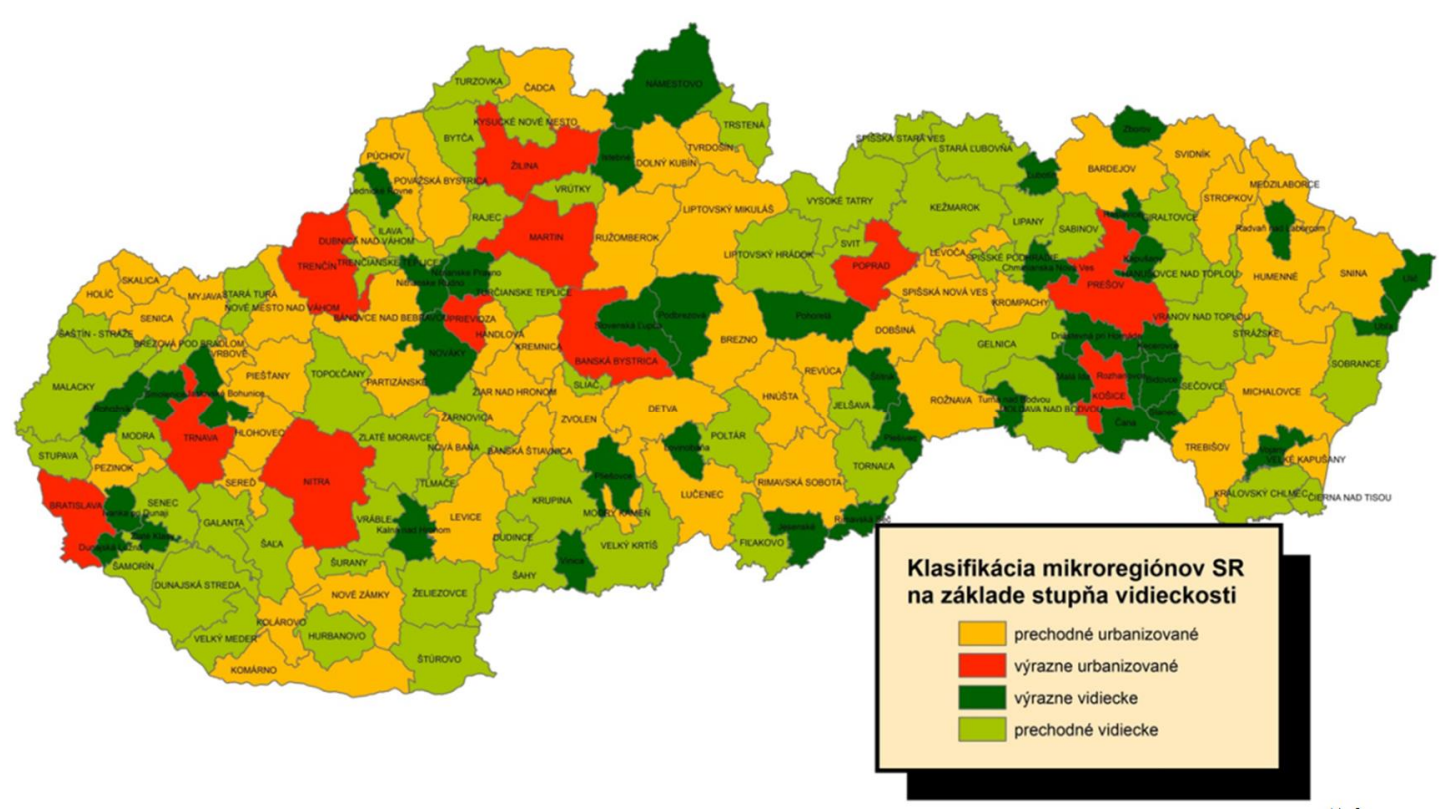

Zdroj: vlastné spracovanie na základe údajov GU SR (2013)

Predmetom prípadovej guúdie bol mikroregión výrazne vidieckeho charakteru, ktorý sa vyznal oval najvyğgou hodnotou LQ kreatívnych odvetví. Výskumná vzorka predstavovala 42 subjektov zo zadefinovaných skupín (tvorcovia kreatívneho obsahu ï 29, profesijné zdruǵenia a organizácie ï 1 , vzdelávacie inġitúcie $\ddot{i} ~ 2$, inġitúcie verejnej správy ï 10). Pri identifikácii potenciálnych respondentov sme vychádzali z databázy Registra organizácií Slovenskej republiky, v rámci ktorej sme identifikovali kđ̛̣il ové subjekty v danej oblasti, ktoré sme následne oslovili. Interview s takto vybranými respondentmi prebiehalo individuálne s kaǵdým respondentom a osobne. Poḷ as realizácie interview boli zistené podstatné diskrepancie údajov z RO SR a reálnou situáciou. Následne sme preto implementovali tzv. Âsnowball samplingñ t.j. respondovaní kđ̣̆il oví aktéri v mikroregióne sprostredkovali stretnutia s N̦alğmi relevantnými subjektmi, aǵ kým nebol dosiahnutý kritický pol et respondentov. Definovaných bolo 7 typov vzŠahov medzi respondentmi uvedených v analytickej ! asti príspevku. Pri kvantifikácii väzieb v rámci kreatívneho klastra sme implementovali analytický aparát teórie grafov. Mnoğina subjektov, ktoré boli zahrnuté do výskumu a ich vzájomných relácií tvorí multidigraf, pril om respondované subjekty sú vrcholmi tohto grafu a identifikované väzby medzi subjektmi sú hranami grafu (Abas, - Híc, 2005). Na teórii grafov bola zaloǵená aj sieŠová analýza, ktorá predstavuje analýzu matice vzŠahov (v teórii grafov adjacentná matica), ktorá bola kvantitatívne vyhodnotená za pomoci softvéru UCINET 6 a vizualizovaná pomocou softvéru NetDraw. Okrem uvedených boli pouǵité aj nástroje softvéru ArcView. 


\section{Výsledky}

Vzhădom na to, ǵe potenciálne kreatívne klastre vo výrazne vidieckych mikroregiónoch sú lokalizované najmä v mikroregiónoch tohto typu situovaných v bezprostrednej blízkosti Bratislavskej aglomerácie (Babjaková, Chreneková, 2013), v záujme abstrahovaŠod vplyvov generovaných mestom Bratislava (kde predpokladáme prevaǵné pôsobenie aglomeral ných a difúznych efektov), boli mikroregióny územne prislúchajúce Bratislavskému kraju zo základného súboru vyradené.

\section{Obr. 2: Lokaliza!̣ný kvocient kreatívnych subjektov v mikroregiónoch SR po vyradení mikroregiónov prislúchajúcich Bratislavskému kraju (2013)}

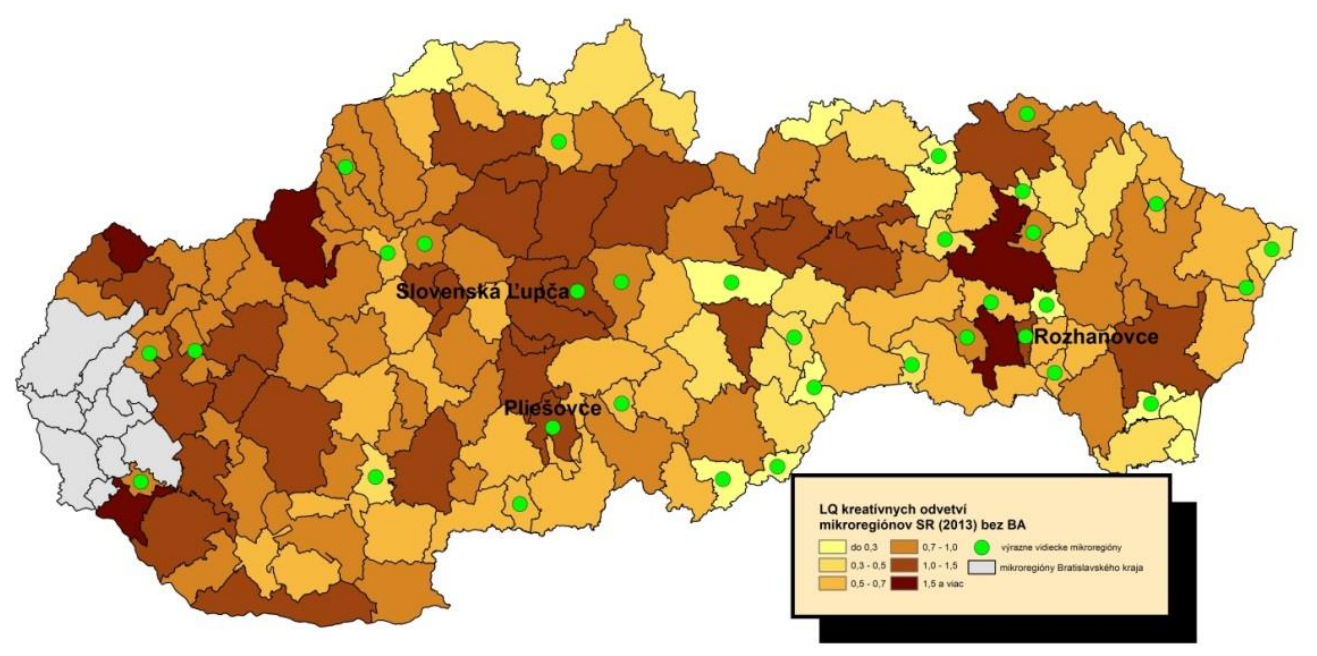

Zdroj: vlastné spracovanie na základe údajov RO SR (2013)

Aj po abstrahovaní od vplyvu hlavného mesta krajiny, relatívne vyg̈g̉e hodnoty LQ kreatívnych odvetví vykazujú tie výrazne vidiecke mikroregióny, ktoré sú situované v blízkosti urbanizovaných mikroregiónov. (Minimálne) nadproporḷ né zastúpenie kreatívnych subjektov zo súboru výrazne vidieckych mikroregiónov bolo identifikované v troch mikroregiónoch: Slovenská ōup! a $(\mathrm{LQ}=1,13)$, Plieǵovce (LQ=1,07) a Rozhanovce (LQ=1,01), zvýraznených na obrázku !..2.

Obr. 3: Odvetvová ġruktúra kreatívnej ekonomiky v jednotlivých typoch mikroregiónov SR a troch potenciálnych vidieckych kreativnych klastroch ï zastúpenie subjektov (2013)

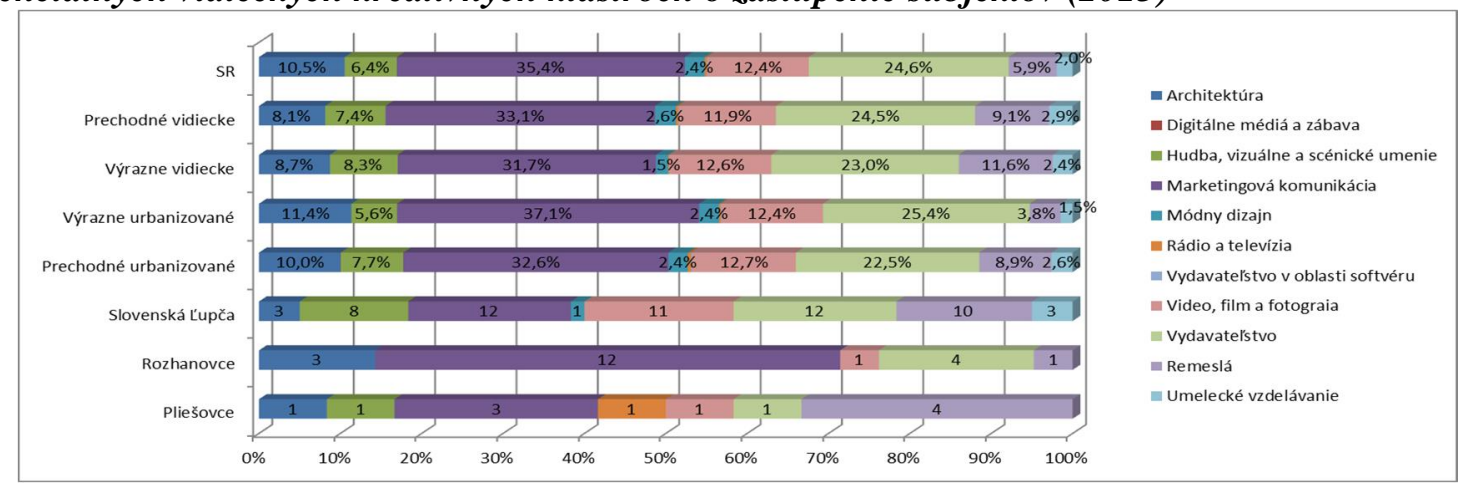

Zdroj: vlastné spracovanie na základe údajov RO SR (2013)

Skupina mikroregiónov s najvyğġm stupŔom vidieckosti v porovnaní s ostanými sa vyznal uje relatívne vyğgim zastúpením odvetví remeselných a hudby, vizuálneho a scénického umenia. $\mathrm{Z}$ troch identifikovaných potenciálnych vidieckych kreatívnych klastrov má najdiverzifikovanejg̉u odvetvovú ġruktúru mikroregión Slovenská ōupla a, ktorý sa v porovnaní s priemerom výrazne vidieckych regiónov vyznalıje relatívne vyğğm zastúpením odvetví vydavateQ̆tva, hudby, vizuálneho 
a scénického umenia, remesiel a umeleckého vzdelávania. Centrum mikroregiónu Slovenská ōupḷ a bolo servisným remeselným mestom nielen pre okolité sídla, ale v tomto kontexte malo aj nadnárodný význam. Vzhădom na odvetvovú ǵruktúru a pol et subjektov konğatujeme, ǵe najvhodnejğm priestorom pre skúmanie kreatívnych klastrov vo vidieckych oblastiach je práve tento mikroregión, keṆǵe v ostatných identifikovaných mikroregiónoch neexistuje kritický pol et týchto subjektov pre vznik klastra.

\section{Integrácia kreatívnych odvetví v mikroregionálnej ġruktúre}

Kvantifikáciou väzieb prítomných medzi jednotlivými skupinami respondovaných kreatívnych subjektov a N̦alğch relevantných aktérov pôsobiacich v mikroregióne sme potvrdili viacero teoretických predpokladov. Posudzovali sme indikátory, ktoré ilustrujú hustotu väzieb medzi respondovanými subjektmi (vyjadruje podiel existujúcich hrán grafu na vg̉etkých moğných hranách za daného poḷ tu vrcholov), stupeŔ !̣lenov (vyjadruje poḷ et hrán, s ktorými daný vrchol inciduje) a tendenciu vytváraŠv rámci siete lokálne sub-ğruktúry (vyjadrenú koeficientom klastrovania).

Tab. 1: Kvantitatívne charakteristiky sociálneho kapitálu a formálnych väzieb v kreatívnych odvetviach v mikroregióne Slovenská öup!̣a

\begin{tabular}{|c|c|c|c|c|}
\hline Typ vzŠahu & Hustota relácií & Pol et hrán & $\begin{array}{c}\text { Priemerný } \\
\text { stupeŔ vrcholov }\end{array}$ & $\begin{array}{c}\text { Koeficient } \\
\text { klastrovania } \\
\text { grafu }\end{array}$ \\
\hline Neformálne vzŠahy & 0,071 & 542 & 6,159 & 0,375 \\
\hline Spolupráca na spolo!̣ ných projektoch & 0,029 & 222 & 2,523 & 0,262 \\
\hline Poskytovanie finan! nej pomoci a sponzorstva & 0,001 & 9 & 0,102 & 0,000 \\
\hline Tok informácií a poradenstva & 0,020 & 151 & 1,716 & 0,290 \\
\hline L̦lenstvo v rovnakých organizáciách & 0,008 & 64 & 0,727 & 0,555 \\
\hline Zamestnanecké vzŠahy & 0,001 & 6 & 0,068 & 0,000 \\
\hline DodávateQ̆ké vzŠahy & 0,004 & 30 & 0,341 & 0,000 \\
\hline OdberateQ̆ké vzŠahy & 0,010 & 74 & 0,841 & 0,027 \\
\hline
\end{tabular}

Zdroj: vlastné spracovanie na základe výsledkov primárneho výskumu

Medzi subjektmi kreatívnych odvetví a N̦alğmi aktérmi lokalizovanými v mikroregióne Slovenská ōupl a ako najvýznamnejğe boli identifikované neformálne vzŠahy, spolupráca na projektoch a výmena informácií a know-how, pril om respondenti uvádzajú naj! astejg̈e práve neformálne vzŠahy. Tendenciu vytváraŠzhluky majú prirodzene v rámci zoskupovania do organizácií a zdruǵení (Obr. 8). Zdruǵujú sa predovğetkým verejné subjekty ï obce (miestne ak!̣ né skupiny). 
Obr. 4: Interakcie subjektov kreatívnych odvetví a relevantných subjektov v mikroregióne Slovenská öup!a

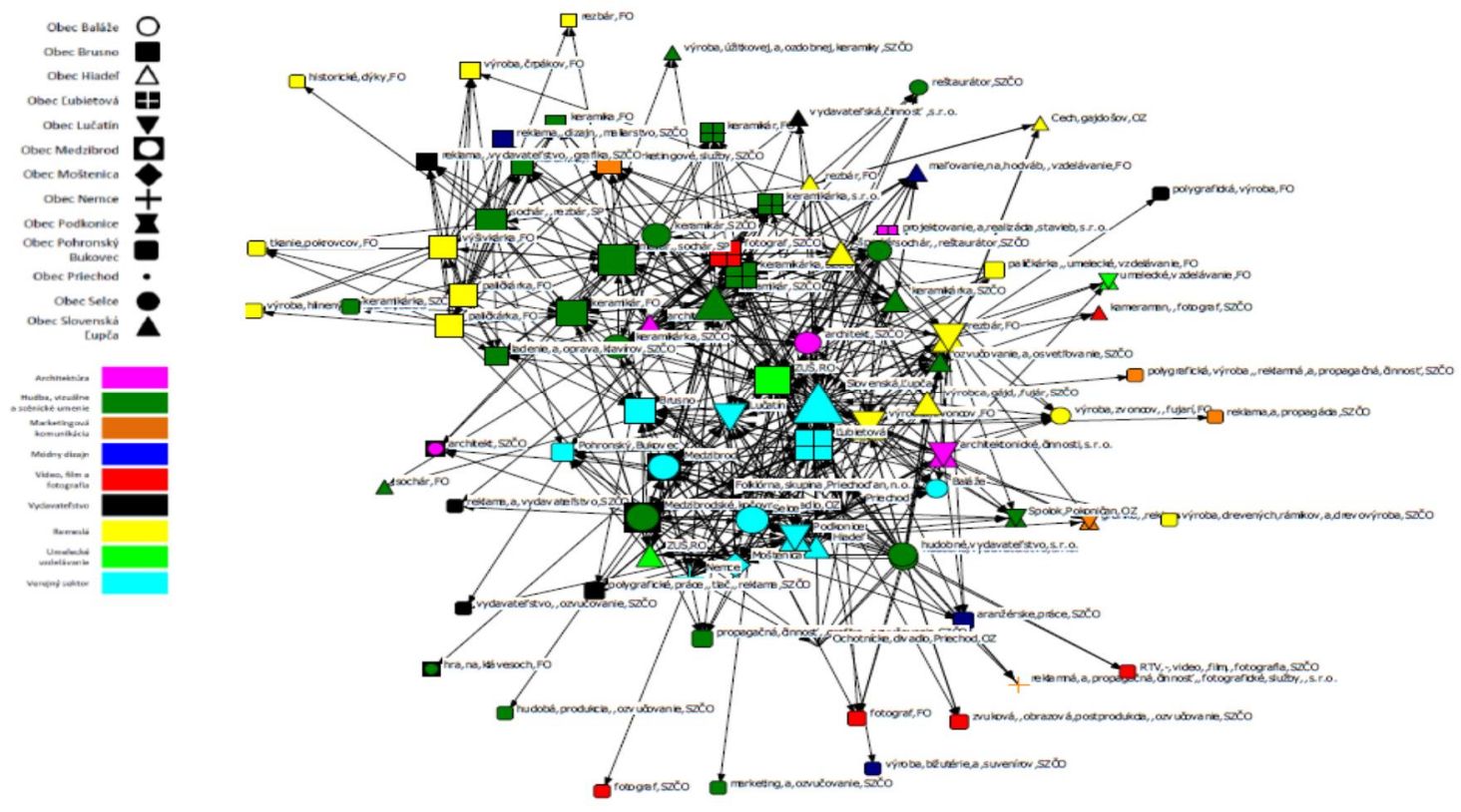

Zdroj: vlastné spracovanie na základe výsledkov primárneho výskumu

Z hădiska hustoty a frekvencie interakcií (Obr. 4) najvýznamnejg̉e postavenie majú reprezentanti verejného sektora, subjekty umeleckých odvetví, niektoré subjekty remesiel a nezanedbateŏé postavenie majú aj základné umelecké g̉koly (veđ̆osŠ zobrazenia !̣ lena v sieti je odvodená od pol tu väzieb na ostaných ! lenov). Z hădiska vytvárania zhlukov identifikujeme tendenciu uǵǵej spolupráce v rámci odvetví (diferencované farbou !l lena) a to práve odvetví, ktoré sú v mikroregióne najzastúpenejğe, ale aj z priestorového hădiska (diferencované tvarom ! lena), ! o znamená, ǵe uğgie spolupracujú subjekty lokalizované v rovnakých obciach. Subjekty, ktoré sa nachádzajú na periférii siete spravidla patria do odvetví videa, filmu a fotografie, marketingovej komunikácie a vydavateQ̆tva. Tieto odvetvia, preto môǵeme $\mathrm{z}$ hădiska fungovania kreatívneho klastra v mikroregióne povaǵovaŠza podporné odvetvia vzhădom ku kđ̆ı̣ ovým.

Podobná dynamika vzŠahov platí aj v rámci spolupráce na spolo!̣ných projektoch (Obr. 7), ktorú uskutol Ŕujú prevağne jednotlivé obce, pril om vğłk pri analýze zhlukovania bolo zistené, ǵe spolol né projekty sú realizované aj umelcami a remeselníkmi, za úl asti subjektov podporných odvetví. V rámci toku informácií a poradenstva (Obr. 9) sme tieǵ identifikovali niekođ̆o zhlukov. Transfer poznatkov a know-how je najvýraznejğ vo verejnom sektore a zhădiska kreatívnych odvetví medzi remeselníkmi, zatiaŌ o umelci si informácie vymieŔajú navzájom aj s architektmi a remeselníkmi. Hustota finan!ných tokov medzi respondentmi je relatívne nízka a v tomto kontexte dominuje podpora obḷianskych zdruǵení a vzdelávacích inğitúcií zo strany miestnej samosprávy. Analýza zamestnaneckých vz Šahov nasvedl uje významné postavenie inğitúcií umeleckého vzdelávania v územných klastroch kreatívnych odvetví. Pôsobenie kreatívnych subjektov v umeleckých g̉kolách je pre nich výhodou z najmä $\mathrm{z}$ hădiska zabezpel enia doplnkového príjmu, ! o má v nadväznosti na charakter nestálosti príjmu z predaja umeleckej tvorby veăxý význam. Okrem toho im vzdelávacie inġitúcie poskytujú vhodnú platformou pre nadväzovanie spolupráce. V tomto prípade ide o symbiotický vzŠah, nakoăxo aj kreatívni pracovníci pôsobiaci vo vzdelávacích inġitúciách majú dopad na fungovanie týchto organizácií a to prostredníctvom poskytnutia praktických skúseností pre giakov a ich integrácie do profesionálnej sféry.

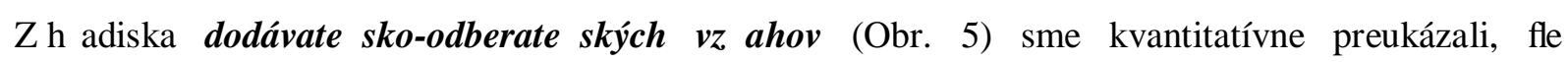
významným odberateQ̆m produktov odvetvia hudby, vizuálneho a scénického umenia je aj miestna samospráva, ktorá je tieǵ významným odberateŎm výstupov architektonických !̣ inností. Ġecifickou 
formou podpory zo strany obcí je nákup výrobkov a iných výstupov kreatívnych subjektov, ktoré obce pouğ́vajú ako propagal ný materiál (napr. pri návg̉evách mimo regiónu, v zahraniḷí). Architekti lokalizovaní v mikroregióne veŎni frekventovane spolupracujú s verejným sektorom, !̣ i uǵ pri tvorbe územných plánov a súvisiacich strategických dokumentov, tak aj pri vypracovaní guúdií investil ných projektov realizovaných obcami. V tomto aspekte produkty odvetví ako sú marketingová komunikácia, video, film a fotografia a vydavateQ̆tvo sú vstupmi bázických kreatívnych odvetví a to primárne na odbytovej strane ï reklama, podpora predaja a pod.

V kreatívnom klastri absentujú odbytové kanály (galérie, kluby a pod.). Vzhădom na skutoḷ nosŠ ǵe odbytový trh kđ̣̆! ových kreatívnych odvetví siaha za hranice mikroregiónu je opodstatnenosŠ existencie uvedených druhov odbytových kanálov v mikroregióne diskutabilná.

V rámci siete väzieb kreatívnych subjektov a N̦alğch relevantných rozvojových aktérov v mikroregióne evidujeme silný sociálny kapitál medzi jednotlivými segmentmi ako aj jednotlivými subjektmi (najvyğgia hustota väzieb práve v rámci neformálnych vzŠahov) a ing̉itucionálne zázemie, ktoré patria aj medzi dôvody relatívne vysokého gádia vývoja analyzovaného kreatívneho klastra, !o je najlepg̈e ilustrované slovami jednej starostky, ktorá tvrdí, ğe lokalizácia a úspeg̉nosŠ týchto odvetví Ă..závisí ja od schopných aktérov, ktorí sa v regióne zídu, ktorí dokáğ́ pritiahnuŚaj financie zvonka, spolupracovaŠs podnikateăkými subjektmiñ s ḷím sa zhoduje aj ! asŠ respondentov, slovami jedného z nich: Ăvýznamná je existencia komunity a organizaḷne agilných Q̊dí a moğ́osti spolupráce s obcouñ

Obr. 5: Dodávateăko-odberate Q̆ké vzŠahy v rámci kreatívneho klastra v mikroregióne Slovenská ōup!̣a

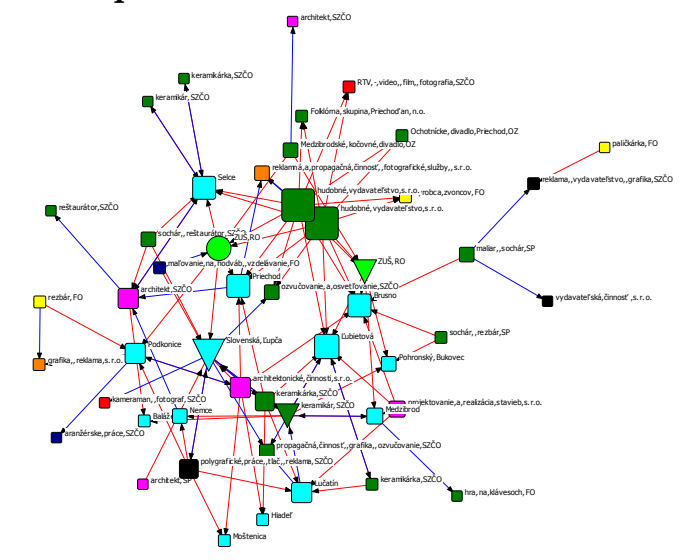

Obr. 6 Neformálne $v z$ Šahy $v$ rámci kreatívneho klastra v mikroregióne Slovenská ōup! $a$

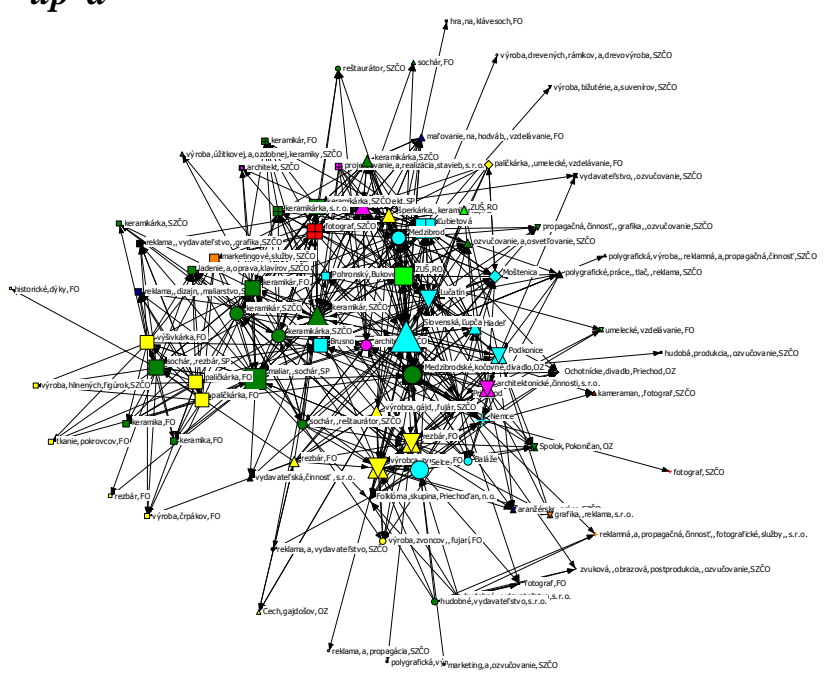


Obr. 7: Spolupráca na projektoch v rámci kreatívneho klastra v mikroregióne Slovenská öup! $a$

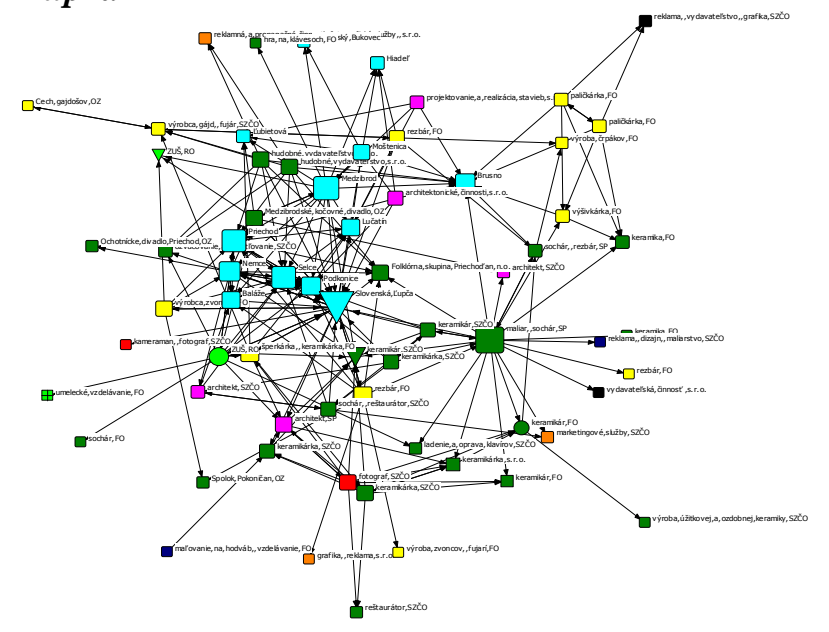

Obr. 9: Tok informácií a poradenstva v rámci kreatívneho klastra v mikroregióne Slovenská öup! $a$
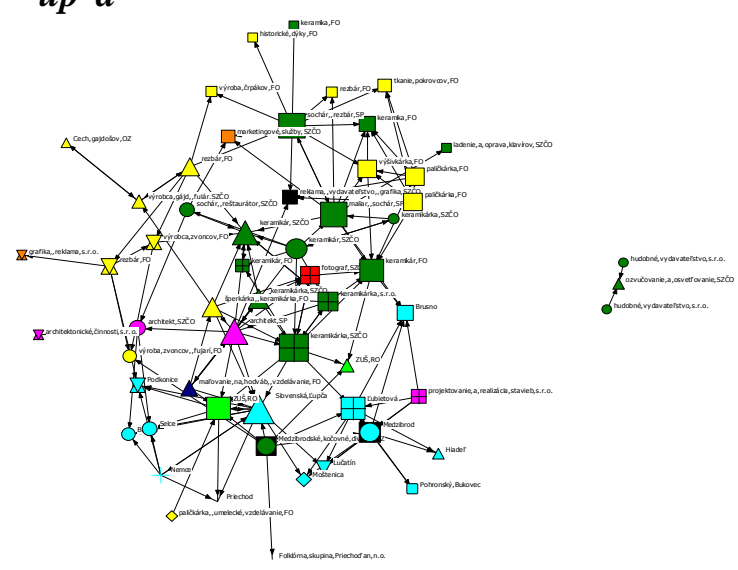

Obr. 8: Llenstvo v spolo!̣ných organizáciách $v$ rámci kreatívneho klastra v mikroregióne Slovenská ōup!̣a
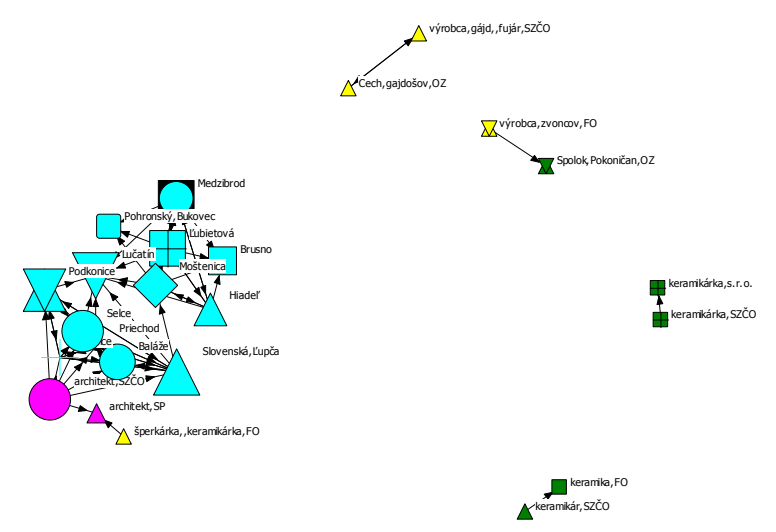
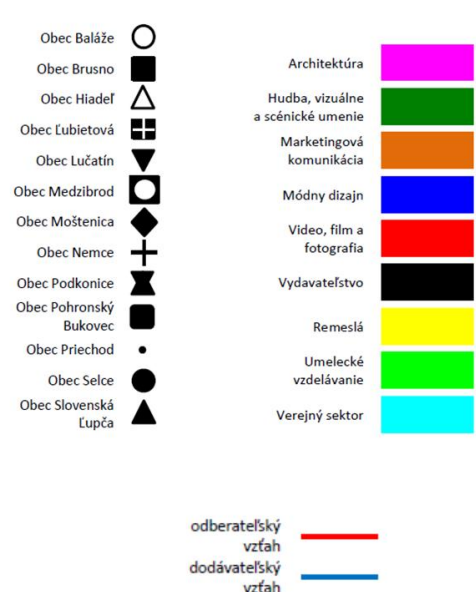

Zdroj: vlastné spracovanie na základe výsledkov primárneho výskumu

\section{Záver}

Kvantitatívne boli dokázané teoretické predpoklady o lokalizal ných tendenciách kreatívnych odvetví, ktoré sa koncentrujú primárne v urbanizovanom prostredí, lím zúrol ujú aglomeral né výhody, ktoré toto prostredie poskytuje. V podmienkach Slovenska je jasne definovaný kreatívny klaster v Bratislavskej aglomerácii a jej okolí (hlavné mesto krajiny má výrazné difúzne pôsobenie na svoje okolie). V kontexte vidieckych a periférnych regiónov Slovenska a kreatívnej ekonomiky sú výsledky pol iatol ných analýz pesimistické. V týchto regiónoch vğa z hQ̆diska kreatívnych odvetví významné postavenie majú hudba, vizuálne a scénické umenie a remeslá, ktorých lokalizácia a koncentrácia je podmienená predovǵtkým g̣pecifickými lokalizal nými faktormi ï existenciou kultúrneho dedil stva, hmotnej a nehmotnej kultúry a génia loci daného prostredia; evidujeme tzv. Ápath dependencyñ t.j. závislosŠ súlasnej ğruktúry ekonomickej základne na vývojovej trajektórii analyzovaného mikroregiónu. Na základe výsledkov prípadovej guúdie predpokladáme, ǵe kreatívne klastre vo vidieckom prostredí sú zaloǵené na vzŠahoch skôr neformálneho charakteru, v rámci ktorých sa uskutol Ŕaje aj intenzívny transfer poznatkov a Ăknow-howñ nielen medzi kreatívnymi subjektmi navzájom, ale aj medzi nimi a ostatnými významnými rozvojovými aktérmi v priestore, z ktorých významné postavenie má miestna samospráva a vzdelávacie inġitúcie. Tieto poskytujú pre kreatívnych jednotlivcov nielen zdroj doplnkového príjmu, ale aj vhodnú platformu pre spoluprácu 
kreatívnych subjektov v regióne. Verejné subjekty sú v rámci kreatívnych klastrov vo vidieckom prostredí výrazne integrované a významne ovplyvŔujú úroveŔ organizovanosti a spolupráce medzi kreatívnymi subjektmi a kreatívnymi odvetviami. Koncentrácia kreatívnych subjektov vo vidieckom prostredí vyúsŠuje v budovanie sociálneho kapitálu a spolol enského konsenzu miestnych a regionálnych aktérov rozvoja (tzv. kreatívneho milieu), ! o je fundamentálnym predpokladom efektívneho vyuğ́vania existujúcich endogénnych a exogénnych rozvojových zdrojov. Efekty priesakov sa teda prejavujú nielen v rámci kreatívnych odvetví ako takých, ale aj v rámci ġrg̈ej ekonomiky, dokonca celej komunity, generujúc významné pozitívne externality a verejný úǵtok.

\section{Literatúra}

[1] ABAS, M., HÍC, P., (2005). Diskrétna matematika. Vysokog̉kolské skriptá, STU Bratislava. DOI 10.1007/BF01887900.

[2] ANDERSSON, A. E., (1985). Creativity and regional development. Papers of the regional science association., iss. 56, pp. 5-20.

[3] APVV 0101-10. Kreatívna ekonomika Ï národohospodárske a regionálne podmienky a stimuly (KRENAR)

[4] ARLINGHAUS, L., SANDRA et al., (1996). Practical handbook of spatial statistics. New York: CRC Press. ISBN: 0-8493-0132-7. p. 307.

[5] BABJAKOVÁ, B., CHRENEKOVÁ, M., (2013). Creative industries in Nitra region. In Regional economics in new perspectives. Winter seminar of regional science. Bratislava: VydavateQ̆tvo Ekonóm. ISBN 978-80-225-3607-3.

[6] FÁZIKOVÁ, M., STEHLíKOVÁ, B., (2006). Nové prístupy ku klasifikácii vidieckych regiónov = New approaches to the classification of rural regions. Ekonomika po ̋̆ohospodárstva, vol. 6, iss. 2, pp. 23-29. ISSN 1335-6186.

[7] FLORIDA, R., (2003). Cities and the Creative Class, In City \& Community, vol. 2, iss. 1, pp. 3ï 19. DOI 10.1111/1540-6040.00034.

[8] FlORIDA, R., MELLANDER, Ch., STOLARICK, K., (2007). Inside the Black Box of Regional Development: Human Capital, the Creative Class and Tolerance. CESIS Electronic Working Paper, !. 88. [online]. [cit. 2014-3-11] Dostupné na: Ûnttp://www.infra.kth.se/cesis/documents/WP88.pdfü

[9] KLAMER, A., (2011). Cultural entrepreneurship. In The Review of Austrian Economics, vol. 24, iss. 2, pp. 141-156. DOI 10.1007/s11138-011-0144-6.

[10] LAZZERETTI, L., BOIX, R., CAPONE, F., (2009). Why do Creative Industries Cluster? An analysis of the determinants of clustering of creative industries. IERMB Working Paper in Economics, no. 09.02.

[11] LORENZEN, M., ANDERSEN, V. K., (2007). The Geography of the European Creative Class: A RankSize Analysis, DRUID Working Paper, no. 07-17. ISBN 978- 87-7873-246-0.

[12] MARKUSSEN, A., (2006). Urban development and the politics of a creative class: evidence from the study of artists. In Environment and Planning A., vol. 38, iss. 10, pp. 1921-1940.

[13] MUNOZ, P., OôTOOLE, M., (2011). ÓBeyond Talent, Diversity and Technology: Transforming Small Cities into Creative Placesô Newcastle University Business School, working paper. [online]. [cit. 2014-311] Dostupné z: Ûtttp://sustainableinnova.wordpress.com/2010/04/28/beyond-talent-diversity-andtechnology/ü

[14] PORTER, M. E., (2000). Location, competition, and economic development: Local clusters in a global economy. In Economic development quarterly: Sage Publications, vol. 14, iss. 1, pp. 15-34.

[15] REHÁK, Ġ, CHOVANEC, M., (2012). Exploring creative clusters using micro-geographic data. ERSA conference papers: European Regional Science Association [online]. [cit. 2014-2-18] Dostupné z: Ûhttp://ideas.repec.org/p/wiw/wiwrsa/ersa12p562.htmlü

[16] SCOTT, A. J., (1997). The Cultural Economy of Cities. In International Journal of Urban and Regional Research, vol. 21, iss. 2, pp. 323-339.

[17] SLAVÍK, V., KOG̣UCH, M., BAḶ̂́K, V., RAGAḶOVÁ, M., (2005). Analýza mikroregiónov Slovenskej republiky. Projekt rieǵený pre splnomocnenca vlády SR pre decentralizáciu verejnej správy, [online]. [cit. 2014-2-11]. Dostupné z: Ûhttp://www.komunal.eu/subory/Mikroregiony_Slovenska.pdfü

Príspevok bol vypracovaný v rámci grantu APVV 0101-10 Kreatívna ekonomika ï národohospodárske a regionálne podmienky a stimuly 